\title{
Pengukuran Kualitas Dengan Deming Prize Tools Di PT. XYZ
}

\author{
Mohammad Rachman Waluyo \\ Program Studi Teknik Industri, Fakultas Teknik \\ Universitas Pembangunan Nasional "Veteran" Jakarta \\ Jl. RS. Fatmawati No. 1, Pondok Labu, Jakarta Selatan \\ Email : aanvicenzo@gmail.com
}

\begin{abstract}
Abstraks
Perusahaan XYZ adalah perusahaan yang memproduksi berbagai macam produk furniture mulai lemari, meja, sofa, kitchen set. Untuk sementara perbaikan yang dilakukan oleh perusahaan lebih banyak dititik beratkan terhadap kualitas produk (eksternal). Padahal kualitas produk harus ditunjang kualitas internal perusahaan yang mempengaruhi kualitas produk yang dihasilkan. Performansi perusahaan dari segi kualitas di era ini cukup bagus, untuk itu harus ditingkatkan dalam upaya mempertahankan diri dan bersaing dengan perusahaan lain, perusahaan membutuhkan dasar pedoman pengukuran manajemen kualitas sebagai acuaan/pembanding pengukuran ditahun-tahun kedepannya, sehingga diketahui posisi perusahaan saat ini bagaimana. Salah satu cara yang dapat dilakukan adalah dengan mengetahui persepsi para karyawan mengenai perusahaan berdasarkan ukuran-ukuran yang telah ditetapkan sehingga perusahaan dapat mengetahui performansinya dan tujuan yang telah ditetapkan. Salah satu taktik strategi usaha dan berorientasi pada kepuasan konsumen dengan melibatkan seluruh anggota organisasi yang berfokus pada variable internal perusahaan yakni dengan Total Quality Management dengan menggunakan Deming Prize. Berdasarkan hasil dan analisa data, dapat diketahui bahwa score untuk variabel organisasi sebesar 3,18, standarisasi sebesar 3,06, pengendalian sebesar 2,70, analisis sebesar 2,61 dan pengaruh sebesar 3,22, kebijakan dan saran sebesar 3.63, pendidikan dan pelatihan sebesar 3.85, pengumpulan dan penyebaran informasi sebesar 3,83 , jaminan mutu sebesar 3.87, rencana dan masa depan sebesar 3.81. Dimana nilai-nilai tersebut telah melebihi target score yang telah ditetapkan dari masing-masing variabel.
\end{abstract}

Kata Kunci $\quad$ : Total Quality Management, Deming Prize, Persepsi Karyawan

\section{Pendahuluan}

Persaingan global memberikan banyak keuntungan pada konsumen dan berdampak berat bagi produsen, dimana mereka semakin sadar biaya (cost conscious) dan sadar nilai (value conscious) dalam meminta produk dan jasa yang berkualitas tinggi supaya dapat bertahan dan berhasil dalam lingkungan persaingan [1]. Perusahaan harus menciptakan value bagi konsumen dalam bentuk produk dan jasa serta pelayanan yang berkualitas sehingga perusahaan juga memperoleh value [2].

PT. XYZ bergerak di bidang furniture, agar tetap eksis dituntut untuk tetap menjaga eksistensinya atau kelangsungan hidup perusahaan dengan terus menjaga kualitasnya. Untuk mencapai misi tersebut perusahaan menerapkan tools Total Quaity Management (TQM). Dimana dalam TQM semua usaha manajemen harus diarahkan pada tujuannya yaitu terciptanya kepuasan konsumen [3]. PT. XYZ merupakan perusahaan yang menurut studi lapangan sudah cukup bagus tetapi manajemen juga membutuhkan pengukuran manajemen kualitas dengan menggunakan metode TQM [4] berbasis Deming Prize yang digunakan untuk dasar pedoman pengukuran dasar manajemen kualitas dan sebagai pembanding pengukuran manajemen kualitas di tahun berikutnya karena mengutamakan konsistensi melalui pengembangan suatu sistem yang dapat mendukung kinerja para pekerjanya. Variabel/instrumen yang berhubungan dengan permasalahan akan dianalisa $[9,10]$ sebagai berikut :

1. Variabel Terikat

- Kualitas Manajemen 
Kualitas manajemen adalah kualitas yang dapat menghasilkan produk dalam memenuhi kebutuhan dan harapan konsumen berkaitan dengan umur sebuah produk.

2. Variabel Bebas

- Organisasi

Keadaan perusahaan secara umum meliputi tugas karyawan, interaksisosial antar karyawan/departemen, pembagian tugas karyawan. Dari sini dapat diketahui gambaran awal perusahaan seperti apa dan perbaikan apa yang dapat dilakukan.

- Standarisasi

Pengamatan ini mencakup masalah bagaimana perusahaan menerapkan teknologi didalam proses kerjanya, atau dari sisi organisasi termasuk masalah alat kerja, serta masalah penerapan teknologi dan stándar karyawan.

- Pengendalian

Pengendalian perlu dilakukan untuk menjaga agar prosedur yang diterapkan terhadap kualitas yang mungkin terjadi dari waktu ke waktu.

- Análisis

Bagaimana cara meningkatan metode kerja, kesadaran karyawan akan produktifitas dalam usaha peningkatan kualitas untuk perusahaannya itu sendiri.

- Pengaruh

Dari semua proses kinerja karyawan, serta penerapan pengendalian kualitas diperusahaan, maka akan dilihat sejauh mana kegiatan tersebut telah berhasil dilaksanakan. Baik itu dari mutu sampai kepuasan pelanggan.

- Variabel Kebijakan dan Saran

- Variabel Pendidikan dan Pelatihan

- Variabel Pengumpulan dan Penyebaran Informasi

- Variabel Jaminan Mutu

Variabel rencana Masa Depan

Kualitas menjadi hal utama bagi setiap perusahaan yang selalu mengarah pada produk yang berkualiatas, harga bersaing dan tepat waktu. Artinya setiap pelanggan selalu menginginkan produk dengan kualitas yang bagus dengan harga murah/bersaing dan dapat diperoleh pada saat dibutuhkan oleh pelanggan dengan focus kepuasan pelanggan [5]. Perkembangan teknologi dan masih adanya peluang pasar menyebabkan menjamurnya perusahaan-perusahaan baru dan konsumen sekarang yang mulai kritis menimbulkan masalah baru bagi perusahaan dalam hal peningkatan kualitas, yakni:

1. Tuntutan konsumen terhadap barang yang semakin bermutu

2. Kesetiaan konsumen terhadap produk semakin berkurang

3. Persaigan harga yang tidak sehat

Situasi persaingan yang seperti ini, perusahaan dituntut untuk menggunakan sistem manajemen yang baik dimana sistem manajemen ini dapat dijadikan sebagai alat untuk meningkatkan kinerja perusahaan. Salah satu alat manajemen yang bisa digunakan adalah TQM yang berbasis Deming Prize [6].

\section{Metodelogi Penelitian}

Alat yang digunakan adalah kuisioner dengan skala liket (1-5) [7]. Penyebaran data dimulai pada bulan Januari 2017 hingga data yang dibutuhkan cukup. Jenis penelitian ini masuk kedalam jenis penelitian Eksplanatori. Populasi subjek penelitian ini adalah manajemen dan karyawan PT. XYZ. Pembuatan kuisioner didasarkan pada lima kategori Deming Prize yang mengacu pada 10 poin Deming [8], dan telah disesuaikan dengan kondisi riil perusahaan. Kuisioner disebar sebanyak 30 orang menggunakan data populasi [7]. Teknik penelitian ini menggunakan alat bantú SPSS 23, untuk mengetahui validitas dan reliabilitas dari data penyebaran kuisioner dan data pengujian validitas dan reliabilitas 10 point Deming Prize. 


\section{Hasil Dan Pembahasan}

a. Organisasi

Koefisien korelasi variabel organisasi, standarisasi, pengendalian, análisis dan pengaruhkebijakan dan saran, pendidikan dan pelatihan, pengumpulan dan penyebaran informasi, jaminan mutu dan rencana masa depan masing-masing item valid dibandingkan angka kritis nilai $\mathrm{r}$ ( $\mathrm{r}$ tabel) pada tingkat signifikan 5\%.

Tabel 1. Perbandingan Score Perhitungan Dengan Target Score

\begin{tabular}{|c|l|c|c|c|}
\hline NO & \multicolumn{1}{|c|}{ Kategori } & $\begin{array}{c}\text { Pertanyaan } \\
\text { NO }\end{array}$ & $\begin{array}{c}\text { Score } \\
\text { persh }\end{array}$ & $\begin{array}{c}\text { Target } \\
\text { score }\end{array}$ \\
\hline 1 & Keterlibatan & 1 & 4,03 & 3,5 \\
\hline 2 & Kerjasama & $2-3$ & 3,63 & 3,5 \\
\hline 3 & Pelatihan & 4 & 3,83 & 3,5 \\
\hline 4 & Struktur organisasi & 5 & 3,53 & 3,5 \\
\hline 5 & Staffing & 6 & 3,67 & 3,5 \\
\hline 6 & Wewenang tertinggi & 7 & 1,77 & 1,5 \\
\hline 7 & Job analysis & $8-9$ & $1,35^{*}$ & 1,5 \\
\hline & Total (Jumlah Score Dibagi 7) & & $\mathbf{3 , 1 8}$ & $\mathbf{2 , 9 3}$ \\
\hline
\end{tabular}

Sumber: Data Primer Diolah

\section{Keterangan: (*) Perlu Perbaikan}

Untuk variabel organisasi, score yang diperoleh perusahaan $(3,18)$ melebihi dari target score yang ditetapkan $(2,93)$. Hal ini berarti secara umum perusahaan telah menerapkan prosedur kategori diatas. Namun ada satu item yang yang bidawah target score yaitu job analysis yang masih harus ditingkatkan yang selama ini karyawan merasa tidak pernah dilibatkan atau pun dimintai saran dalam usaha peningkatan kualitas di dalam perusahaan. Hal ini, menunjukan bahwa masalah keterlibatan karyawan menjadi masalah yang harus diperhatikan oleh pihak perusahaan. Kategori yang termasuk kedalam variabel organisasi adalah:

a. Keterlibatan

Karyawan adalah orang yang pertama kali mengetahui apakah proses produksi berjalan dengan baik atau tidak dan sekaligus mengetahui masalah-masalah yang datang di perusahaan.

b. Kerjasama

Hubungan antara departemen dalam perusahaan terjalin baik sehingga memudahkan bekerjasama untuk memecahkan persoalan secara tim.

c. Pelatihan

Para karyawan mendapat pelatihan tentang pekerjaanya dan tentang usaha perbaikan proses dimana ia bekerja, karena perbaikan proses berlangsung secara terus menerus dan kualitas merupakan sasaran yang terus mengalami perubahan.

d. Struktur Organisasi

Dimana untuk mengetahui bagaimana kejelasan wewenang dan tanggung jawab dalam menjalankan kualitas dalam susunan organisasi.

e. Staffing Pengantian karyawan atau keluar masuknya karyawan jarang dilakukan oleh perusahaan ini.

f. Job Analysis

Perusahaan belum melakukan survey/ meminta pendapat karyawan dalam usaha memperbaiki kualitas yang diperlukan.

g. Wewenang Tertinggi 
Pimpinan mewakili wewenang penuh terhadap peningkatan kualitas perusahaan, dan yang harus ditekankan adalah seberapa besar komitmen perusahaan terhadap peningkatan kualitas.

\section{b. Standarisasi}

Tabel 2 Perbandingan Score Perhitungan Dengan Target Score

\begin{tabular}{|c|l|c|c|c|}
\hline NO & \multicolumn{1}{|c|}{ Kategori } & $\begin{array}{c}\text { Pertanyaan } \\
\text { NO }\end{array}$ & $\begin{array}{c}\text { Score } \\
\text { persh }\end{array}$ & $\begin{array}{c}\text { Target } \\
\text { score }\end{array}$ \\
\hline 1 & Tujuan unit kerja & 10 & 4,53 & 3,5 \\
\hline 2 & Tujuan organisasi & 11 & 3,63 & 3,5 \\
\hline 3 & Karateristik tugas karyawan & 12 & 3,57 & 3,5 \\
\hline 4 & Sadar akan produktivitas & 13 & 3,63 & 3,5 \\
\hline 5 & Konsekuensi pembatas & $14-15$ & 3,66 & 3,5 \\
\hline 6 & Definisi tool/alat kerja & 16 & 1,97 & 1,5 \\
\hline 7 & Perkembangan organisasi & 17 & 1,63 & 1,5 \\
\hline 8 & Rencana penerapan kualitas & 18 & 1,93 & 1,5 \\
\hline & Total (Jumlah Score Dibagi 8) & & $\mathbf{3 , 0 6}$ & $\mathbf{2 , 7 5}$ \\
\hline
\end{tabular}

Sumber: Data Primer Diolah

Untuk variabel standarisasi score yang diperoleh melebihi dari target score $(3,06)$ yang ditetapkan $(2,75)$. Hal ini berarti secara umum perusahaan telah menerapkan prosedur kategori diatas, untuk itu perlu dipertahankan dan ditingkatkan.

\section{c. Pengendalian}

Tabel 3. Perbandingan Score Perhitungan Dengan Target Score

\begin{tabular}{|c|l|c|c|c|}
\hline NO & \multicolumn{1}{|c|}{ Kategori } & $\begin{array}{c}\text { Pertanyaan } \\
\text { NO }\end{array}$ & $\begin{array}{c}\text { Score } \\
\text { persh }\end{array}$ & $\begin{array}{c}\text { Target } \\
\text { score }\end{array}$ \\
\hline 1 & Metode/proses peningkatan & 19 & 3,97 & 3,5 \\
\hline 2 & Kuantitatif/jumlah & 20 & 3,63 & 3,5 \\
\hline 3 & Sistem/stuktur peningkatan kualitas & 21 & 3,87 & 3,5 \\
\hline 4 & Rencana strategi & $22-23$ & 1,73 & 1,5 \\
\hline 5 & Proses/ukuran analisa & 24 & 1,93 & 1,5 \\
\hline 6 & Pengukuran & $25-32$ & 1,59 & 1,5 \\
\hline & Total (Jumlah Score Dibagi 6) & & $\mathbf{2 , 7}$ & $\mathbf{2 , 5}$ \\
\hline
\end{tabular}

Sumber: Data Primer Diolah

Untuk variabel pengendalian score yang diperoleh $(2,7)$ melebihi dari target score $(2,5)$ yang ditetapkan. Hal ini berarti secara umum perusahaan telah menerapkan prosedur kategori diatas untuk itu perlu dipertahankan dan ditingkatkan 
Jurnal Teknologi dan Manajemen Industri, Vol. 4 No. 1, Februari 2018

Pascasarjana Institut Teknologi Nasional Malang

\section{d. Analisis}

Tabel 4. Perbandingan Score Perhitungan Dengan Target Score

\begin{tabular}{|c|l|c|c|c|}
\hline NO & \multicolumn{1}{|c|}{ Kategori } & $\begin{array}{c}\text { Pertanyaan } \\
\text { NO }\end{array}$ & $\begin{array}{c}\text { Score } \\
\text { persh }\end{array}$ & $\begin{array}{c}\text { Target } \\
\text { score }\end{array}$ \\
\hline 1 & Sadar akan produktivitas & 13 & 3,63 & 3,5 \\
\hline 2 & Metode / proses peningkatan & 19 & 3,97 & 3,5 \\
\hline 3 & Proses / ukuran analisa & 24 & 1,93 & 1,5 \\
\hline 4 & Evaluasi & $33-34$ & 1,78 & 1,5 \\
\hline 5 & Definisi improvement & 35 & 1,77 & 1,6 \\
\hline & Total (Jumlah Score Dibagi 5) & & $\mathbf{2 , 6 1}$ & $\mathbf{2 , 3 2}$ \\
\hline
\end{tabular}

Sumber: Data Primer Diolah

Untuk variabel pengendalian score yang diperoleh $(2,61)$ melebihi dari target score yang ditetapkan $(2,32)$. Hal ini berarti secara umum perusahaan telah menerapkan prosedur kategori diatas untuk itu perlu dipertahankan dan ditingkatkan

\section{e. Pengaruh}

Tabel 5. Perbandingan Score Perhitungan Dengan Target Score

\begin{tabular}{|c|l|c|c|c|}
\hline NO & \multicolumn{1}{|c|}{ Kategori } & $\begin{array}{c}\text { Pertanyaan } \\
\text { NO }\end{array}$ & $\begin{array}{c}\text { Score } \\
\text { persh }\end{array}$ & $\begin{array}{c}\text { Target } \\
\text { score }\end{array}$ \\
\hline 1 & Supply bahan-bahan & 36 & 4,67 & 3,5 \\
\hline 2 & Survey kualitas pada pelanggan & 37 & 3,73 & 3,5 \\
\hline 3 & Reabilitas & 38 & 3,60 & 3,5 \\
\hline 4 & Peralatan & 39 & 3,57 & 3,5 \\
\hline 5 & Fasilitas & 40 & 3,73 & 3,5 \\
\hline 6 & Metode/proses penigkatan & 19 & 3,70 & 3,5 \\
\hline 7 & Masukan karyawan & 41 & $1,33^{*}$ & 1,4 \\
\hline 8 & Penghargaan & $42-43$ & $1,45^{*}$ & 1,5 \\
\hline & Total (Jumlah Score Dibagi 8) & & $\mathbf{3 , 2 2}$ & $\mathbf{2 , 9 9}$ \\
\hline
\end{tabular}

Sumber: Data Primer Diolah

\section{Keterangan: * perlu perbaikan}

Untuk variabel pengaruh score yang diperoleh $(3,22)$ melebihi dari target score yang ditetapkan $(2,99)$. Hal ini berarti secara umum perusahaan telah menerapkan prosedur kategori diatas. Dari kelima kategori berpengaruh terdapat dua item yang nilai score perusahaan dibawah nilai target score dan untuk tahun kedepannya perlu ditinggkatkan.

Item masukan karyawan untuk mengetahui apakah perusahaan telah menggunakan sebuah tim untuk menyelesaikan atau pun memecahkan masalah. Keaktifan karyawan didalam perusahaan serta pengaruh karyawan bagi perusahaan dirasa masih kurang. Disini perusahaan perlu melakukan penambahan intensitas terhadap pemberdayaan karyawan.

PT. XYZ diera sekarang ini belum ada kelompok gugus kendali mutu yang dapat memberikan tambahan informasi terhadap perusahaan. Perusahaan hanya menginginkan karyawannya untuk berorientasi penuh terhadap pekerjaan, sedangkan masalah yang lainnya perusahaan belum melibatkan karyawan. Hendaknya perusahaan perlu membentuk suatu kelompok kecil dari beberapa karyawan yang berkompeten yang ada di departemen yang bersangkutan untuk memantau kinerja perusahaan. Meminta masukan mengenai kemungkinan adanya masalah yang timbul, jika memungkinkan ikut dilibatkan pengambilan keputusan yang berkaitan dengan kebijakan perusahaan, sehingga dengan 
begitu semakin banyak masukan dari karyawan maka semakin kecil pula masalah yang muncul didalam perusahaan.

Item penghargaan yang dibahas dalam kuisioner ingin mengetahui sejauh mana kepuasan karyawan dalam pemberian bonus atau pun kenaikan jabatan didalam perusahaan. Hasilnya banyak dari karyawan perusahaan yang merasa pihak perusahaan belum secara optimal memberiakan bonus atau pun promosi kepada karyawan yang telah bekerja dengan baik. Masalah penghargaan didalam perusahaan merupakan masalah yang dilematis. Disatu sisi karyawan ingin mendapatkan penghargaan yang lebih namun disisi lain perusahaan perlu menyesuiakan dengan kondisi keuangan perusahaan.

Masalah bonus atau penghargaan perusahaan hanya memberikan bonus kapada karyawan bila meraka melakukan lembur. Sedangkan mereka yang berprestasi belum ada penghargaan yang berarti. Agar karyawan lebih terpacu untuk bekerja lebih baik, hendaknya peruasahaan dapat memberi penghargaan/ bonus kepada karyawan dalam beberpa periode tertentu agar karyawan lebih bersemangat dalam bekerja.

Dari kedua masalah diatas tentu dapat dijadikan bahan pertimbangan bagi pihak perusahaan untuk menerapkan hak tersebut, tetapi harus disesuiakan dengan kondisi internal perusahaan. Pertimbangan diatas memudahkan perusahaan untuk menilai karyawan mana yang berhak mendapat penghargaan/bonus tentu akan lebih mudah bila perusahaan membentuk tim gugus kendali mutu didalam perusahaan dengan melibatkan beberpa karyawan.

\section{f. Kebijakan Dan Saran}

Tabel 6. Score untuk Variabel Kebijakan dan Saran

\begin{tabular}{|c|l|c|c|c|}
\hline NO & \multicolumn{1}{|c|}{ Kategori } & $\begin{array}{c}\text { Pertanyaan } \\
\text { NO }\end{array}$ & $\begin{array}{c}\text { Score } \\
\text { persh }\end{array}$ & $\begin{array}{c}\text { Target } \\
\text { score }\end{array}$ \\
\hline 1 & Rapat karyawan & 44 & 4,07 & 3,5 \\
\hline 2 & Meminta saran & 45 & $3,07^{*}$ & 3,5 \\
\hline 3 & Rencana dari karyawan & 46 & $3,43^{*}$ & 3,5 \\
\hline 4 & Tuntutan dari perusahaan & 47 & 3,93 & 3,5 \\
\hline 5 & Hubungan dengan perusahaan lain & 48 & 3,53 & 3,5 \\
\hline 6 & Requipment & 49 & 3,67 & 3,5 \\
\hline 7 & Quality improvement & 50 & 3,73 & 3,5 \\
\hline & Total (Jumlah Score Dibagi 7) & & 3,63 & $\mathbf{3 , 5}$ \\
\hline
\end{tabular}

Sumber: Data Primer Diolah

Untuk variabel Kebijakan dan Saran yang diperoleh $(3,63)$ melebihi dari target score yang ditetapkan $(3,5)$. Hal ini berarti secara umum perusahaan telah menerapkan prosedur kategori diatas untuk itu perlu dipertahankan dan ditingkatkan dari ketuju kategori Variabel kebijakan dan saran terdapat dua item yang nilai score perusahaan dibawah nilai target score (meminta saran, rencana dari karyawan) dan untuk tahun kedepannya perlu ditinggkatkan/dikomodasi.

\section{g. Pendidikan Dan Pelatian}

Tabel 8. Perbandingan Score Perhitungan Dengan Target Score

\begin{tabular}{|c|l|c|c|c|}
\hline NO & \multicolumn{1}{|c|}{ Kategori } & $\begin{array}{c}\text { Pertanyaan } \\
\text { NO }\end{array}$ & $\begin{array}{c}\text { Score } \\
\text { persh }\end{array}$ & $\begin{array}{c}\text { Target } \\
\text { score }\end{array}$ \\
\hline 1 & Manfaat pendidikan 1 & 51 & 4,13 & 3,5 \\
\hline 2 & Manfaat pendidikan 2 & 52 & 3,67 & 3,5 \\
\hline 3 & Pemblajaran organisasi & 53 & 3,53 & 3,5 \\
\hline 4 & Bahaya ketiadaan pelatihan & 54 & 3,83 & 3,5 \\
\hline 5 & Pelatihan secara continue & 55 & 3,73 & 3,5 \\
\hline
\end{tabular}




\begin{tabular}{|l|l|c|c|c|}
6 & Pengembangan dari pelatihan 1 & 56 & 4,00 & 3,5 \\
\hline 7 & Pengembangan dari pelatihan 2 & 57 & 4,07 & 3,5 \\
\hline & Total (Jumlah Score Dibagi 7) & & 3,85 & $\mathbf{3 , 5}$ \\
\hline
\end{tabular}

Sumber: Data Primer Diolah

Untuk variabel Pendidikan dan pelatian yang diperoleh $(3,85)$ melebihi dari target score yang ditetapkan $(3,5)$. Hal ini berarti secara umum perusahaan telah menerapkan prosedur kategori diatas untuk itu perlu dipertahankan dan ditingkatkan dari ketujuh kategori variabel pendidikan dan pelatian.

\section{h. Pengumpulan Dan Penyebaran Informasi}

Tabel 9. Perbandingan Score Perhitungan Dengan Target Score

\begin{tabular}{|c|l|c|c|c|}
\hline NO & \multicolumn{1}{|c|}{ Kategori } & $\begin{array}{c}\text { Pertanyaan } \\
\text { NO }\end{array}$ & $\begin{array}{c}\text { Score } \\
\text { persh }\end{array}$ & $\begin{array}{c}\text { Target } \\
\text { score }\end{array}$ \\
\hline 1 & Saran dari pelanggan & 58 & 3,67 & 3,5 \\
\hline 2 & Informasi & 59 & 4,07 & 3,5 \\
\hline 3 & Pembentukan tim & 60 & 3,83 & 3,5 \\
\hline 4 & Penyebaran informasi & 61 & 3,73 & 3,5 \\
\hline 5 & Mencari informasi & & 3,87 & 3,5 \\
\hline & Total (Jumlah Score Dibagi 5) & 3,83 & $\mathbf{3 , 5}$ \\
\hline
\end{tabular}

Sumber: Data Primer Diolah

Untuk variabel pengumpulan dan penyebaran informasi yang diperoleh $(3,83)$ melebihi dari target score yang ditetapkan $(3,5)$. Hal ini berarti secara umum perusahaan telah menerapkan prosedur kategori diatas untuk itu perlu dipertahankan dan ditingkatkan dari 5 kategori variabel pengumpulan dan penyebaran informasi.

\section{i. Jaminan Mutu}

Tabel 10. Perbandingan Score Perhitungan Dengan Target Score

\begin{tabular}{|c|l|c|c|c|}
\hline NO & \multicolumn{1}{|c|}{ Kategori } & $\begin{array}{c}\text { Pertanyaan } \\
\text { NO }\end{array}$ & $\begin{array}{c}\text { Score } \\
\text { persh }\end{array}$ & $\begin{array}{c}\text { Target } \\
\text { score }\end{array}$ \\
\hline 1 & Analisa 1 & 63 & 4,07 & 3,5 \\
\hline 2 & Analisa 2 & 64 & 4,00 & 3,5 \\
\hline 3 & Pesaing & 65 & 3,73 & 3,5 \\
\hline 4 & Perbaikan 1 & 66 & 3,83 & 3,5 \\
\hline 5 & Perbaikan 2 & 67 & 3,67 & 3,5 \\
\hline 6 & Inovasi & 68 & 3,97 & 3,5 \\
\hline 7 & Produktif 1 & 70 & 3,63 & 3,5 \\
\hline 8 & Produktif 2 & 71 & 3,87 & 3,5 \\
\hline 9 & Pelanggan & 72 & 3,03 & 3,5 \\
\hline 10 & Peralatan & & $\mathbf{3 , 8 7}$ & 3,5 \\
\hline & Total (Jumlah Score Dibagi 10) & $\mathbf{3 , 5}$ \\
\hline
\end{tabular}

Sumber: Data Primer Diolah

Untuk variabel Jaminan Mutu yang diperoleh $(3,87)$ melebihi dari target score yang ditetapkan $(3,5)$. Hal ini berarti secara umum perusahaan telah menerapkan prosedur kategori diatas untuk itu perlu dipertahankan dan ditingkatkan dari sepuluh kategori variabel Jaminan Mutu. 
Jurnal Teknologi dan Manajemen Industri, Vol. 4 No. 1, Februari 2018

Pascasarjana Institut Teknologi Nasional Malang

\section{j. Rencana Masa Depan}

Tabel 11. Perbandingan Score Perhitungan Dengan Target Score

\begin{tabular}{|l|l|c|c|c|}
\hline NO & Kategori & $\begin{array}{c}\text { Pertanyaan } \\
\text { NO }\end{array}$ & $\begin{array}{c}\text { Score } \\
\text { persh }\end{array}$ & $\begin{array}{c}\text { Target } \\
\text { score }\end{array}$ \\
\hline 1 & Teknologi & 73 & 4,53 & 3,5 \\
\hline 2 & Rencana jangka panjang 1 & 74 & 3,63 & 3,5 \\
\hline 3 & Perbaikan 1 & 75 & 3,57 & 3,5 \\
\hline 4 & Rencana jangka panjang 2 & 76 & 3,63 & 3,5 \\
\hline 5 & Evaluasi & 77 & 3,60 & 3,5 \\
\hline 6 & Kepemimpinan & 78 & 3,73 & 3,5 \\
\hline 7 & Perbaikan 2 & 79 & 4,07 & 3,5 \\
\hline 8 & Perbaikan 3 & 80 & 3,83 & 3,5 \\
\hline 9 & Usulan untuk masa depan & 81 & 3,73 & 3,5 \\
\hline & Total (Jumlah Score Dibagi 10) & & $\mathbf{3 , 8 1}$ & $\mathbf{3 , 5}$ \\
\hline
\end{tabular}

Sumber: Data Primer Diolah

Untuk variabel variabel rencana masa depan yang diperoleh $(3,81)$ melebihi dari target score yang ditetapkan $(3,5)$. Hal ini berarti secara umum perusahaan telah menerapkan prosedur kategori diatas untuk itu perlu dipertahankan dan ditingkatkan dari sepuluh kategori variabel rencana masa depan.

\section{Usulan Rencana Perbaikan Bagi Perusahaan}

Dari penjabaran yang telah dianalisa diatas ada 4 variabel yang manjadi masalah bagi perusahaan. Masalah yang dimaksud adalah masalah kurangnya keterlibatan dari karyawan, kurang didengarnya rencana dan aspirasi mereka dalam kegiatan perusahaan serta masalah pemberian bonus ataupun kenaikan jabatan yang dirasa kurang oleh karyawan perusahaan. Dalam rencana usulan perbaikan bagi pihak perusahaan, akan dijelaskan secara singkat mengenai pemecahan dari keempat masalah yang ada didalam perusahaan.

Salah satu prinsip TQM adalah pemberdayaan dan pelibatan karyawan (PPK). Untuk mensukseskannya ada berbagai cara, di antaranya adalah:

a) Kotak saran

Memberikan kotak saran di tempat-tempat yang sering didatangi karyawan, agar karyawan dapat meletakan saran-saran tertulisnya untuk perbaikan perusahaan itu sendiri.

b) Gugus kualitas (Quality Circle)

Gugus kualitas adalah kelompok karyawan yang mengadakan pertemuan secara teratur untuk mengedintifikasi, menganjurkan dan membuat perbaikan lingkungan kerja. Perbedaan utama antara gugus kualitas adalah bahwa anggota gugus kualitas adalah para sukarelawan yang melaksanakan pertemuan sendiri. Gugus kualitas bertemu secara teratur untuk melakukan perubahan untuk mendiskusikan pekerjaan, mengantisipasi dan mencari solusi masalah, menawarkan perbaikan lingkungan kerja dan menetapkan tujuan serta membuat rencana.

Pembahasan selanjutnya menyangkut masalah penghargaan yang dirasa masih kurang oleh para karyawan di PT. XYZ. Didalam model TQM, peranan penghargaan dan pengakuan terhadap prestasi karyawan, seperti penilaian kerja, kompensasi, program pengakuan prestasi dan sistem promosi merupakan motivasi untuk mencapai sasaran perusahaan. Berikut ini akan dijabarkan mengenai prinsip-prinsip kunci kualitas mengenai sistem kompensasi.

a) Kompensasi harus berorientasi pada pelanggan

Upah atau gaji diberikan kepada karyawan yang memiliki keterampilan untuk memuaskan kebutuhan pelanggan. Untuk melakukan hal tersebut karyawan harus mengetahui kebutuhan dan harapan pelanggan serta apa yang telah dilakukan oleh perusahaan untuk memenuhi kebutuhan dan harapan pelanggan tersebut.

b) Kompensasi harus berorientasi pada tim 
TQM mengisyaratkan dibentuknya tim. Jadi, kompensasi pada pencapaian sasan tim, bukan sasaran individu.

Beberapa usulan pemberian sistem kompensasi diatas diharapkan dapat menjadi acuan bagi pihak perusahaan dalam memberi tambahan bonus kepada karyawan serta memperbaiki sistem kompensasi diperusahaan. Dalam penerapannya, tentu diperlukan analisa yang lebih mendalam menyangkut masalah financial perusahaan. Hasil analisa ini seyogyanya menjadi pedoman PT. XYZ dalam mengukur TQM focus pada Deming Prize.

\section{Kesimpulan}

Berdasarkan hasil analisis dan pembahasan yang telah dilakukan, maka dapat disimpulkan sebagai berikut :

1. Kualitas internal di PT. XYZ secara umum sudah cukup baik, hal ini terbukti dari score-score yang didapat dari 10 variabel, yaitu :

Untuk variabel Organisasi, Standarisasi, Pengendalian, Analisis, Pengaruh, Kebijakan dan saran, pendidikan dan pelatihan, pengumpulan dan penyebaran informasi, jaminan mutu dan rencana masa depan, semua score perusahaan diatas target. Dimana ada dua kategori yang masih dibawah target score yang ditetapkan, yakni kategori masukan karyawan dengan score 1,33 masih dibawah target score yang sebesar 1,40 serta bonus dan penghargaan yang score perusahaannya 1,45 masih dibawah target score yang ditetapkan yakni 1,50

2. Rencana perbaikan bagi pihak perusahaan yang dapat diterapkan dengan menyangkut beberapa kekurangan yang ada diperusahaan, antara lain :

a) Masukan karyawan

b) Pemberian kompensasi bagi karyawan dengan menggunakan prinsip-prinsip sistem kompensasi

\section{DAFTAR PUSTAKA}

[1]. Deming, W. E. 1982. Quality, Productivity and Competitive Position, Massachusetts Institute of Technology, Cambridge.

[2]. Gaspersz, V. 2005. Total Quality Management. Jakarta: PT. Gramedia Pustaka Umum.

[3]. Ghozali, Imam. 2016. Aplikasi Analisis Multivariate dengan Program IBM SPSS 23. Semarang: Badan Penerbit Universitas Diponegoro.

[4]. Ibrahim, Buddy. 2000. Total Quality Management - Panduan Untuk Menghadapi Persaigan Global, Penerbit Djambatan, Jakarta.

[5]. Lakhal, L., Pasin, F., And M. Liman. 2006. Quality Management Practices and Their Impact on Performance. International Journal of Quality And Reliability Management. Vol, 23. No. 6: Pp. $625-646$.

[6]. Nasution, M, N. 2005. Manajemen Mutu Terpadu: Total Quality Management, Edisi Kedua, Ghalia Indonesia, Bogor.

[7]. Ramlawati. 2010. Implikasi Praktek Total Quality Management (TQM) Terhadap Daya Saing, Kepuasan Konsumen, dan Kinerja Bisnis pada Perusahaan Manufaktur di Kota Makassar, Disertasi Pps. Feuniversitas Brawijaya, Malang.

[8]. Sit, W.-Y., Ooi, K.-B., Lin, B. and Chong, A.Y.-L. 2009. TQM and Customer Satisfaction in Malaysia's Service Sector. Industrial Management and Data Systems. Vol.109, No.7, Pp. 957975.

[9]. Evans, James R. dan William M. Lindsay. 2011. The Management and Control of Quality. Kanada: South-Western Cengage Learning

[10]. Austenfield Jr., Robert. 2001. W. Edwards Deming: The Story of Truly Remarkable Person. Papers Of Research Society Of Commerce And Finance Vol. XXXXII No. 1 